\title{
Should Video Games Be Included in the Learning Process?
}

\author{
Abdulrahman Alamri, ${ }^{1, *}$ \\ ${ }^{1}$ University of North Texas, 1155 Union Circle, \#311277, Denton, TX, 76203-5017, USA \\ *Correspondence: University of North Texas, 1155 Union Circle, \#311277, Denton, TX, \\ 76203-5017, USA. E-mail: Abdulrahmanalamri@my.unt.edu
}

Received: October 3, 2015 Accepted: January 6, 2016 Published: February 26, 2016

doi:10.5296/ije.v8i1.8388 URL: http://dx.doi.org/10.5296/ije.v8i1.8388

\begin{abstract}
Over the last two decades, video games have increasingly become an essential part of the ways of playing and learning. In this paper, we discuss the claim that video games should be included in the learning process based on the argument that video games have educational features, attract students, increase their motivation to study, and help students to use their knowledge in practice. Video games provide an opportunity for fun and effective repetitive practice for children. Traditional learning often fails to generate student interest in what they are studying in class. This lack of interest can result in ineffective learning as, in these cases, students are simply performing in the classroom but do not acquire knowledge. Students need special motivation, which can be provided by video games. However, play video games may also be associated with some negative behaviors such as addiction, hyperactivity, attention problems, and impulsiveness. We discuss the specific ways video games may support learning processes as an attractive way of delivering information and serving knowledge acquisition in the new media era.
\end{abstract}

Keywords: Video Games, Learning and Teaching 


\section{Video Games Can Improve Students' Motivation}

Video games can offer types of motivation such as competition, diversion, enjoyment, fantasy, interest with game, social interaction, and application (Cianfrone, Zhang, \& Jae Ko, 2011), as well as excitement, relaxation, and coping with anger (Olson, 2010). Additionally, games may provide relationship, manipulation, immersion, escapism, and achievement types of motivation (Yee, 2006), which may not exist in traditional learning methods (Molins-Ruano et al., 2014). Video games provide extrinsic and intrinsic motivation and they satisfy players' psychological needs (autonomy, competence, and relatedness independently). These needs as related to video games make students finish the activity as they are usually technology-dependent students (Apostol, Zaharescu, \& Alexe, 2013). Video games have the possibility to teach both formal and informal academic and non-academic skills, and, as fun tools, they motivate students to be more collaborative, promote social learning, share information, and increase their achievements (Kebritch, Hirumi, \& Bai, 2010). Video games have the ability to evoke feelings of strong emotional bonds as a part of the students' experiences (Bengoechea, 2009). Learning can bring emotions similar to any other pleasant experience. If the experience is pleasant, students begin to like the leaning process itself and acquire the motivation to continue and excel.

In Japan, two studies using a mixed method was used to investigate the impact of integrating video games into an existing curriculum. In Study $1(\mathrm{n}=9)$, new words were included in task sheets. The second study $(\mathrm{n}=11)$ included the tasks on vocabulary. Learners were affected positively with the incorporation of video games into the curriculum (Hitosugi, Schmidt, \& Hayashi, 2014). Mifsud (2013) applied video games to learning in Malta and students demonstrated considerable improvement in the study of English as a Second Language (ESL) in comparison to those learners who received only traditional instruction. Seventy-nine percent of the 1,163 students (ages 11-16) felt that video games provided them with an opportunity to acquire new skills. Similarly, $77.5 \%$ of 149 teachers believed that students could learn from video games in a classroom environment. Furthermore, $83 \%$ of 783 parents agreed that educational video games have become an important tool in classroom learning.

Gjedde (2014) conducted research on a Danish public secondary school that used a mixed-method of the qualitative case study, survey evaluations every week to implement curriculum, and models of educational live action role play (edu-LARP). Ninety-eight students participated in the research. Ninety-one percent of students said that they were motivated by to give extra effort through the game play. . In the final survey, $55 \%$ of the learners stated that they felt motivated by gaining points to win the competition, $32 \%$ stated that they felt motivated by the collaborative work to make extra effort, while other motivating factors included the learning achieved (16\%) and the fun of the game itself (13\%) (Gjedde, 2014).

\section{Video Games Enhance Student-Centered Strategies}

Video games enhance students' cognitive skills, particularly with respect to problem solving 
and provide students with practical experience, which helps them understand the material better. Griffiths (2002) stated that "Some evidence suggests that important skills may be built or reinforced by video games. For example, spatial visualization ability (i.e., mentally rotating and manipulating two- and three-dimensional objects) improves with video game playing" (p. 47). In order for the knowledge to be acquired, the material should not be memorized, but applied. Video games allow this to be accomplished in class. This helps student develop their personalities more comprehensively (Al-Washmi, Baines, Organ, Hopkins, \& Blanchfield, 2014).

Van den Heuvel-Panhuizen, Kolovou, and Robitzsch (2013) carried out a study to solve a sequence of early algebra problems at home among five schools that consisted of 253 student participants of ages 10-12. Students were tested before and after the intervention. The problems were showed on a worksheet so that students could write down their answers. Performance was measured by a paper and pencil test, and students demonstrated a significant gain in grade-level performance after the intervention of an online learning game (Van den Heuvel-Panhuizen et al., 2013).

Eseryel, Law, Ifenthaler, Ge, and Miller (2014) investigated complex problem solving development with 88 ninth-grade high school students in the Midwest. Students gained a significant increase in the quality of problem representation after playing the online video game McLarin's Adventures (MMOG). Participants received the pretest of the complex problem scenario before playing the game, then watched a video that announced the competition by video game. The participants played the video game, and subsequently constructed their solution as a post-test solution of the complex problem (Eseryel et al., 2014).

\section{Video Games Environments Can Provide Safe Learning Environments}

Virtual and simulation video games provide safe real environments, which enables them to decrease the time and money of training. Students do not have to go anywhere to try their knowledge in practice. They have a perfect opportunity to apply knowledge in practice without wasting time and financial resources. Such virtual training appears to be very useful in certain fields of activity (Vaz de Carvalho, Lopes, \& Ramos, 2014). For example, Belanich, Orvis, and Sibley (2013) trained 21 military participants ages 19-29. Participants used a PC-based game to identify army background information, virtual weapon familiarization, and virtual marksmanship training. The findings revealed that the game provided great training, simulation, and interactive strategies (Belanich et al., 2013).

Boon-itt, (2012) organized a project to teach 30 students a Production and Operation Management (POM) course by playing a simulation game. The purpose was to teach students through real experience instead of a direct lecture course related to engineering and operations. Students were divided into three groups and studied the theories in order to understand the nature of the game planning. After playing the stimulation game, students responded to the questions they received at beginning. The results revealed that, in 
comparison with the normal lecture system, students improved their knowledge by studying the theories in a real environment.

\section{Video Games Can Simplify Science Learning}

Both teachers and students in classrooms may find it difficult to deal with abstract and multi-dimensional phenomenon and to apply the knowledge of many scientific domains (Anderson \& Barnett, 2013). The National Research Council's (2011) report on games and simulations in science education reported that,

simulations and games have potential to address critical weaknesses in current science education by meeting the individual learning needs of both low achieving and advanced science students, embedding science learning in the context of engaging real-world problems, and improving access to high-quality science learning experiences in formal and informal settings (p. 109).

Muehrer, Jenson, Friedberg \& Husain, (2012) conducted mixed-method research on the use of a science-focused video game in five different secondary school settings in Ontario, Canada. The project included data gathered on general gameplay habits and technology use, as well as informal interviews with teachers and students who played the game. A total of 161 participants played a series of games focused on the "life of a plant" with seven teachers. The activity was completed by 147 students who finished both a pre- and post-quiz in order to determine whether the game helped them retain or change what they knew about scientific processes such as plant cell anatomy and photosynthesis. Participants showed statistically significant improvement on quizzes that were taken after playing the game for approximately one-hour sessions. Marino, Israel, Beecher, and Basham, (2013) carried out a mixed-method approach study design. The quantitative phase involved chi-square analysis of pre- and post-intervention surveys taken by students. The qualitative phase included student and teacher interviews to examine their perceptions about science education video games and student attitudes about science and the work of scientists. Participants were comprised of 34 teachers and 876 students in the $6^{\text {th }}-9^{\text {th }}$ grade from 14 states. All student groups reported that they would prefer to learn science from a video game rather than from traditional text, in a laboratory, or on the Internet. Even for students with learning disabilities, video games were an effective tool in the science classroom as Marino et al. (2014) indicated that the performance of 57 students with learning disabilities from four middle schools in the science classroom improved through using video games and supplemental text as tools that provided students with multiple means of representation and expression.

\section{Video Games Help Students with Disabilities to Manage Their Behaviors}

Video games have features that helped students with disabilities, and chronically-ill patients acquire skills, manage their behavior and attention, and possibly more effective in increasing the students' physical activity through the use of exer-gaming and interactive video games 
(Cai \& Kornspan, 2012). Also, video games were able to develop positive aspects of interactions, and mitigate isolation, particularly for hospitalized students (González-González, Toledo-Delgado, Collazos-Ordoñez, \& González-Sánchez, 2014). Video games have been helpful for students with autism, as Griffiths (2002) points out: "Video games have been used in comprehensive programs to help develop social skills in children and adolescents who are severely retarded or who have severe developmental problems like autism" (p. 48). This work helps to disprove the well-known statement that video games are very harmful for children and can cause only aggression.

Marino et al.(2013) investigated how students' reading level, including students with disabilities, is connected to playing video games at home and their attitudes toward the use of video games in the process of classroom learning. The research was conducted in 14 states with 34 instructors and more than 870 students. The majority of students stated that they wanted to learn the material from a video game rather than from traditional learning from textbooks, laboratory studies, or even the Internet. Experiential study used different techniques to collect data including tests, interviews, observation, and video recording. It consisted of ten participants ranging from 9-16 years old. Video games improved positive expression, satisfaction, effectiveness, motivation, socialization, emotions and learning ability. By using a scale of (1-0) to evaluate the experience of the playability, students raised their satisfaction, where their motivation was about (0.97), immersion (0.96), emotion (0.95), effectiveness (1), and learner ability (0.52). Students also presented the high score of cooperation and neutral expression.

Griffiths (2002) provided evidence of positive results received by students with autism when playing video games. This argument also helps to disprove the fact that the use of video games should be restricted as they can be only harmful for students:

Case studies such as those by Demarest are persuasive. Demarest's account of her own autistic 7-year old son reported that although he had serious deficiencies in language and understanding, and social and emotional difficulties, videogame playing was one activity he was able to excel. This was ego-boosting for him and also had a self-calming effect (Griffiths, 2002, p. 48).

Some researchers have stated that video games cause aggression; therefore, children should spend as little time as possible on the computer. However, the information presented above shows that it is not always so. Children with autism tend to express aggression and nervousness. However, based on the research above, video games have positive effects on calming children with disabilities.

\section{Video Games Are a Favorite Technology at Home}

Teachers should use video games as an integrated technology tool in their classroom as long as games are also a preferred technology at home, since the technology encourages students to enjoy learning in school (Patriarca, Di Giuseppe, Albano, Marinelli, \& Angelillo, 2009). 
Video games are one of the most-preferred types of technology used for playing at home, and are a common pastime for adolescents (Bengoechea, 2009; Drummond \& Sauer, 2014). Moreover, students with autism spend about 2.5 hours per day playing computer games at home. This testifies that including video games into the learning process contributes to students' development when they are used in moderation (Mazurek \& Wenstrup, 2013). Most reported effects of video games, particularly in the popular press, appear to center upon the alleged negative consequences. These have included my own research into video game addiction, increased aggressiveness, and the various medical and psychosocial effects (Griffiths, 2002).

Although $89 \%$ of teachers, before using the video game, disagreed with the idea that video games help develop the curriculum, an experimental study indicated (post-test) that $76 \%$ of teachers fully agree with this idea and $69 \%$ stated that they will definitely start using video games in class. The study conducted in 2012 showed that, after the experiment, many teachers changed their minds about the video games and their use in the classroom (Díaz \& Martín-Párraga, 2014). In particular, children with neurodevelopmental disorders, such as cerebral palsy (CP), are in need of fun and engaging rehabilitation methods to optimize their motivation and increase compliance with motor training through video games at their homes. Sandlund, Dock, Häger, and Waterworth (2012) conducted a qualitative study through semi-structured interviews with parents to examine their perceptions of using low-cost motion interactive video games as home training for their children with mild/moderate cerebral palsy. Participants consisted of 15 families that had taken part in an intervention where they used motion interactive games daily as a form of home training program for their children with CP. The game platform used was EyeToy ${ }^{\circledR}$, Play 3 for PlayStation $2 \circledR$, which is based on video-capture techniques. Findings indicated that the parents' perception of the training was very positive. They expressed the view that motion interactive video games may promote positive experiences of physical training in rehabilitation, where the social aspects of gaming were especially valued.

\section{Lack of Teacher Experience Leads to Learning Game Resistance}

Teachers may not have enough experience with video games and their features to know that they may help as a tool in the classroom. Many teachers avoid using video games in class as they consider this to be the waste of time. Instructors, especially the representatives of an old generation, refuse to use video games in class because they consider them to be just a form of entertainment. This is typically due to the lack of experience in this area and information from mass media. Mass media regularly report cases of children's aggression tied to playing video games. Cuban, Kirkpatrick and Peck, (2001) noted several barriers and challenges, including a lack of preparation time, poor technical support, outdated technologies, inability to sustain interest in the particular lessons, a lack of opportunities for collaboration due to the rigid structure, and short time periods allocated to instruction.

Fifty-eight teachers were asked about their feelings on video games in an experimental study by Kenny and McDaniel (2011). The results indicated that teachers had changed their opinion 
as a result of their participation. Almost $62 \%$ of those asked indicated that their opinions had changed, with $95 \%$ of them indicating that they were more positive about video games as a result of their participation. According to Annetta et al. (2013), after their video game experience, half of the 51 teachers, who were non-gamers, recognized that games should be incorporated into the process of learning (Annetta et al., 2013).

\section{Problems Associated with Videogames}

As mentioned earlier, video games have been associated with negative behavior, hyperactivity, addiction, attention problems, and impulsiveness. Although students with autism generally play video game an average of 2.4 hours daily (Engelhardt \& Mazurek, 2014), some research has indicated that problematic behavior, such as inattention and oppositional behavior, were associated with playing video game. One experiment involved parents of 169 boys who had ASD and ranged between ages 8 to 18 years, who completed a series of questions about activity and screen-based media use. Results indicated that there were significant inattention and oppositional defiant symptoms associated with video games, such as role-playing games.

Research conducted by Linebarger (2015) for a group of US parents/caregivers of 788 preschoolers (2-5 years) indicated that video game exposure was directly associated with increasing levels of hyperactivity in preschool children. Responsive parenting moderated the relation between video game exposure and hyperactivity and attention problems in high-risk preschooler children.

Zorbaz, Ulas, \& Kizildag, (2015) conducted a study consisting of 396 4th and 6th grade primary school students in Turkey. Result found that spending time on the computer and video game addiction rates were found to be positive and meaningful. Result suggested that video game playing time should be moderated. However, as noted earlier, limited time of video game play may allow students to engage in activities that support their cognitive, social, and/or affective development.

Attention problems may also be associated with video game play. According to Gentile, Swing, Lim, \& Khoo (2012) who conducted a study which included 3,034 students from 12 different schools in Singapore. The age of participants ranged between $8-17$ years. Findings revealed that video game playing was associated with subsequent attention problems. The evidence is that violent video game content added uniquely to predicting attention problems beyond the total amount of time played. Specifically, video game violence exposure was uniquely associated with attention problems and impulsiveness when sex, age, race were statistically controlled. Results indicated that children with greater impulsiveness and attention problems spend more time playing video games, which lead to negative predictions about the relationship. 


\section{Conclusion}

The conclusion can be made that, due to their useful features, video games can be considered a preferred technology at home. Video games increase extrinsic and intrinsic motivation, satisfy players' psychological needs (autonomy, competence, and relatedness), and promote collaboration, social learning, sharing of information, and increasing of attainments. In contrast to the traditional learning process, video games provide an interesting motivation. Video games evoke the feeling of strong emotional bonds with students' experience in the classroom and increase the students' physical activity. I believe that video games deserve to be integrated as a technology tool in the classroom. It does not mean that the traditional learning process should be significantly altered, but some changes should be implemented. The usual presentation of a new material can be accompanied by practical tasks in the form of a video game. Certainly, video games should be used in moderation, but should not be completely excluded from the learning process. In spite of the fact that teachers' attitudes indicated the lack of video game experience and the existence of a generation gap, the appropriate training in use of video games will make them change their attitude and start using video games in class.

\section{References}

Al-Washmi, R., Baines, M., Organ, S., Hopkins, G., \& Blanchfield, P. (2014). Mathematics problem solving through collaboration: Game design and adventure. Proceedings of The European Conference on Games Based Learning, 1, 1-9.

Anderson, J. L., \& Barnett, M. (2013). Learning physics with digital game simulations in middle school science. Journal of Science Education and Technology, 22(6), 914-926. http://dx.doi.org/10.1007/s10956-013-9438-8

Annetta, L. A., Frazier, W. M., Folta, E., Holmes, S., Lamb, R., \& Cheng, M. (2013). Science teacher efficacy and extrinsic factors toward professional development using video games in a design-based research model: The next generation of STEM learning. Journal of Science Education and Technology,22(1), 47-61. http://dx.doi.org/10.1007/s10956-012-9375-y

Apostol, S. S., Zaharescu, L. I., \& Alexe, I. L. (2013). Gamification of learning and educational games. Elearning \& Software for Education, 2, 67-72. http://dx.doi.org/10.12753/2066-026X-13-118

Belanich, J., Orvis, K. L., \& Sibley, D. E. (2013). PC-based game features that influence instruction and learner motivation. Military Psychology, 25(3), 206-217. http://dx.doi.org/10.1037/h0094963

Bengoechea, J. (2009). Video games and education: A first empirical research in the Basque Country. Proceedings Of The European Conference on Games Based Learning, 195-201.

Boon-itt, S. (2012). Using a simulation game approach to teach pull and push production 
system concepts. Engineering Management Research, 1(1), 110-116.

Cai, S. X., \& Kornspan, A. S. (2012). The use of exergaming with developmentally disabled students. Strategies, 25(3), 15-18.

Cianfrone, B. A., Zhang, J. J., \& Jae Ko, Y. (2011). Dimensions of motivation associated with playing sport video games: Modification and extension of the Sport Video Game Motivation Scale. Sport, Business and Management: An International Journal, 1(2), 172-189. http://dx.doi.org/10.1108/20426781111146763

Desai, R. A., Krishnan-Sarin, S., Cavallo, D., \& Potenza, M. N. (2010). Video-gaming among high school students: Health correlates, gender differences, and problematic gaming. Pediatrics, 126(6), 1414-1424. http://dx.doi.org/10.1542/peds.2009-2706

Díaz, V., \& Martín-Párraga, J. (2014). Can video games be used to develop the infant stage educational curriculum? Journal of New Approaches in Educational Research, 3(1), 20-25. http://dx.doi.org/10.7821/naer.3.1.20-25

Drummond, A., \& Sauer, J. D. (2014). Daily videogame use and metacognitive knowledge of effective learning strategies. Psychology of Popular Media Culture, 4(4), 342-350. http://dx.doi.org/10.1037/ppm0000049

Engelhardt, C. R., \& Mazurek, M. O. (2014). Video game access, parental rules, and problem behavior: A study of boys with autism spectrum disorder. Autism: The International Journal Of Research And Practice, 18(5), 529-537.

Eseryel, D., Law, V., Ifenthaler, D., Ge, X., \& Miller, R. (2014). An investigation of the interrelationships between motivation, engagement, and complex problem solving in game-based learning. Educational Technology \& Society, 17(1), 42-53.

Gentile, D. A., Swing, E. L., Lim, C. G., \& Khoo, A. (2012). Video game playing, attention problems, and impulsiveness: Evidence of bidirectional causality. Psychology of Popular Media Culture, 1(1), 62-70. http://dx.doi.org/10.1037/a0026969

Gjedde, L. (2014). Potentials of a narrative game-based curriculum framework for enhancing motivation and collaboration. Proceedings of The European Conference On Games Based Learning, 1, 151-158.

González-González, C., Toledo-Delgado, P., Collazos-Ordoñez, C., \& González-Sánchez, J. L. (2014). Design and analysis of collaborative interactions in social educational video games. Computers in Human Behavior, 31, 602-611. http://dx.doi.org/10.1016/j.chb.2013.06.039

Griffiths, M. (2002). The Educational Benefits of Video games. Education and Health Journal, 20(3), 47-51.

Hitosugi, C. I., Schmidt, M., \& Hayashi, K. (2014). Digital game-based learning (DGBL) in the L2 classroom: The impact of the UN's off-the-shelf videogame, Food Force, on learner affect and vocabulary retention. CALICO Journal, 31(1), 19-39. 
http://dx.doi.org/10.11139/cj.31.1.19-39

Kebritchi, M., Hirumi, A., \& Bai, H. (2010). The effects of modern mathematics computer games on mathematics achievement and class motivation. Computers \& Education, 55(2), 427-443. http://dx.doi.org/10.1016/j.compedu.2010.02.007

Kenny, R. F., \& McDaniel, R. (2011). The role teachers' expectations and value assessments of video games play in their adopting and integrating them into their classrooms. British $\begin{array}{llll}\text { Journal of Educational Technology, 42(2), } & \text { 197-213. }\end{array}$ http://dx.doi.org/10.1111/j.1467-8535.2009.01007.x

Linebarger, D. L. (2015). Contextualizing video game play: The moderating effects of cumulative risk and parenting styles on the relations among video game exposure and problem behaviors. Psychology Of Popular Media Culture, 4(4), 375-396. http://dx.doi.org/10.1037/ppm0000069

Marino, M. T., Gotch, C. M., Israel, M., Vasquez, E., Basham, J. D., \& Becht, K. (2014). UDL in the middle school science classroom: Can video games and alternative text heighten engagement and learning for students with learning disabilities? Learning Disability Quarterly, 37(2), 87-99. http://dx.doi.org/10.1177/0731948713503963

Marino, M. T., Israel, M., Beecher, C. C., \& Basham, J. D. (2013). Students' and teachers' perceptions of using video games to enhance science instruction. Journal of Science $\begin{array}{lll}\text { Education } \quad \text { and } & \text { 22(5), 667-680. }\end{array}$ http://dx.doi.org/10.1007/s10956-012-9421-9

Mazurek, M. O., \& Engelhardt, C. R. (2013). Video game use and problem behaviors in boys with autism spectrum disorders. Research in Autism Spectrum Disorders, 7(2), 316-324. http://dx.doi.org/10.1177/1362361313482053

Mifsud, C. L. (2013). Attitudes towards and effects of the use of video games in classroom learning with specific reference to literacy attainment. Research in Education, 90, 32-52. http://dx.doi.org/10.7227/RIE.90.1.3

Molins-Ruano, P., Sevilla, C., Santini, S., Haya, P. A., Rodríguez, P., \& Sacha, G. M. (2014). Designing video games to improve students' motivation. Computers in Human Behavior, 31, 571-579. http://dx.doi.org/10.1016/j.chb.2013.06.013

Muehrer, R., Jenson, J., Friedberg, J., \& Husain, N. (2012). Challenges and opportunities: using a science-based video game in secondary school settings. Cultural Studies of Science Education, 7(4), 783-805. http://dx.doi.org/10.1007/s11422-012-9409-z

National Research Council. (2011). Learning science through computer games and simulations. In M. Honey \& M. Hilton (Eds.), Washington, DC: The National Academies Press.

Olson, C. K. (2010). Children's motivations for video game play in the context of normal development. Review of General Psychology, 14(2), 180. http://dx.doi.org/10.1037/a0018984 


\section{Macrothink}

Patriarca, A., Di Giuseppe, G., Albano, L., Marinelli, P., \& Angelillo, I. F. (2009). Use of television, video games, and computer among children and adolescents in Italy. $B M C$ Public Health, 9, 1-10.

Sandlund, M., Dock, K., Häger, C. K., \& Waterworth, E. L. (2012). Motion interactive video games in home training for children with cerebral palsy: parents' perceptions. Disability and Rehabilitation, 34(11), 925-933. http://dx.doi.org/10.3109/09638288.2011.626489

Van den Heuvel-Panhuizen, M., Kolovou, A., \& Robitzsch, A. (2013). Primary school students' strategies in early algebra problem solving supported by an online game. Educational Studies in Mathematics, 84(3), 281-307. http://dx.doi.org/10.1007/s10649-013-9483-5

Vaz de Carvalho, C., Lopes, M. P., \& Ramos, A. G. (2014). Lean games approaches Simulation games and digital serious games. International Journal of Advanced Corporate Learning, 7(1), 11-16. http://dx.doi.org/10.3991/ijac.v7i1.3433

Yee, N. (2006). The demographics, motivations, and derived experiences of users of massively multi-user online graphical environments. Presence, 15(3), 309-329.

Zorbaz, S. D., Ulas, O., \& Kizildag, S. (2015). Relation between video game addiction and inter family relationships on primary school students. Educational Sciences: Theory And Practice, 15(2), 489-497.

\section{Copyright Disclaimer}

Copyright for this article is retained by the author(s), with first publication rights granted to the journal.

This is an open-access article distributed under the terms and conditions of the Creative Commons Attribution license (http://creativecommons.org/licenses/by/3.0/). 